\title{
Crop Adaptation to Biotic and Abiotic Conditions: Going Wild with Next Generation Sequencing Technologies
}

\author{
Kountche $A B^{1,2,3}$, Kane $N^{4}$, IS Ousseini $i^{1,3,5,6}$ and Yves Vigouroux $Y^{1,6 *}$ \\ ${ }^{1}$ Institute of Research for Development, Montpellier, France \\ ${ }^{2}$ International Crops Research Institute for the Semi-Arid Tropics, Sadoré, Niger \\ ${ }^{3}$ Moumouni University of Niamey, Niger \\ ${ }^{4}$ Senegalese Institute of Agricultural Research, Dakar, Senegal \\ ${ }^{5}$ Research Institute for Development, Niamey, Niger \\ ${ }^{6}$ University of Montpellier II, Montpellier, France
}

\section{Editorial}

We are currently facing tremendous challenges to ensure food security in the coming decades. In addition, predicted climate changes are expected to impact average rainfall and to increase the average temperature in different parts of the world: some of which will lose and some will win. Undoubtedly, most climate conditions will change. Several crops are very sensitive to such variations at critical stages of their development. However, environmental changes are not restricted to climate, and agriculture needs to be adapted to some increasing biotic issues. For example, in the Sahel, a parasitic weed named Striga has a significant impact on the production of pearl millet, sorghum, maize and upland rice. In addition, some pests may spread to new regions as a result of climate changes. To tackle such challenges, part of the solution will be agronomic and another part genetic. Wild related populations have long been thought to represent significant assets for crop improvement. It has already been established that they carry very useful tolerance/resistance genes. One basic reason why wild genetic resources could be so important is that they generally display high genetic diversity. Most of today's main crops underwent what is called a domestication bottleneck, i.e. a reduction in diversity compared to their wild relatives [1]. This lower genetic diversity is also thought to directly lead to lower functional diversity. One major challenge is to exploit wild diversity more rapidly than we use to by identifying genomic regions or alleles linked with important QTL for biotic or abiotic stress tolerance or resistance. Next-generation sequencing (NGS) technologies offer new approaches to decipher wild functional diversity. Here, two examples in pearl millet [Cenchrus americanus (L.) Morrone, comb. nov.] are discussed in which wild diversity could be more easily accessed and better exploited than ever through new NGS technologies.

\section{Pearl Millet Resistance to Striga}

The witch weed Striga hermonthica (Del.) Benth. remains a persistent biotic constraint to grain production of pearl millet [2] Resistance sources have been identified among wild pearl millet relatives [3]. However, the use of these resources has been hampered by the lack of cheap genome-wide marker data such as that provided by single nucleotide polymorphism (SNP) markers. Thanks to increased accessibility (low cost and high-throughput genotyping), NGS is closing the gap between what was traditionally identified as model and non-model organisms for genetic studies [4]. The recent availability of the genotyping-by-sequencing (GBS) approach, which is now feasible even for non-model crops like pearl millet, mean this constraint can now be overcome [5]. Projects to identify Striga resistance QTLs in wild resistant $\times$ susceptible cultivated pearl millet populations using genomewide markers are now feasible thanks to these recent developments.

\section{Pearl Millet Adaptation to Extreme Climate}

Pearl millet is already adapted to growth in the driest environments

in Sahelian regions. However, its wild relative grows in even more arid regions than the cultivated types. It could therefore be a source of adaptation that could benefit the cultivated type in future extreme climatic conditions since hybridization between the two types is still possible. This reservoir is still largely untapped [6], because of our inability to pinpoint the most interesting functional gene or alleles, and the large amount of variability already available to breeding programs from cultivated germplasm. Some recent studies reported candidate genes/alleles tightly linked to important agronomic QTLs (drought, flowering) proving that identification of such genetic markers is possible by genome selection scanning [7-8] and association mapping [9]. One of the most promising approaches is combining association mapping and genome selection scanning [10]. Among these methods, genome selection scan using environmental variables to detect functional alleles is particularly promising [11]. All of these methods are available today and should be more widely used in cultivated germplasm. But we should also more largely tap wild functional diversity, and all these new approaches allow doing it faster than ever.

\section{Conclusion}

Recent developments in sequencing technologies will allow faster identification of genes/alleles controlling important agronomic traits. But one should not forget that the genetic approach is only one part of the solution. Such studies will only be useful if an end product is delivered in the farmer's field. A multidisciplinary approach including breeding, socio-economic studies and agronomy is necessary to proceed from the lab to the effective delivery of innovations in African farmers' fields.

\section{References}

1. Vigouroux $Y$, Barnaud A, Scarcelli N, Thuillet AC (2011) Biodiversity, evolution and adaptation of cultivated crops. CR Biol 334: 450-457.

2. Ejeta G (2007) Breeding for Striga resistance in sorghum: Exploitation of an Intricate Host-parasite Biology. Crop Sci 47: S-216-S-227.

3. Wilson JP, Hess DE, Hanna WW, Kumar KA and Gupta SC (2004) Pennisetum Glaucum Subsp. Monodii Accessions with Striga Resistance in West Africa. Crop Protect 23: 865-870.

*Corresponding author: Vigouroux Y, Institute of Research for Development, Montpellier, France, E-mail: yves.vigouroux@ird.fr

Received April 23, 2013; Accepted April 25, 2013; Published April 30, 2013

Citation: Kountche AB, Kane N, Ousseini IS, Vigouroux Y (2013) Crop Adaptation to Biotic and Abiotic Conditions: Going Wild with Next Generation Sequencing Technologies. Agrotechnol 2: e103. doi:10.4172/2168-9881.1000e103

Copyright: (c) 2013 Kountche AB, et al. This is an open-access article distributed under the terms of the Creative Commons Attribution License, which permits unrestricted use, distribution, and reproduction in any medium, provided the original author and source are credited. 
Citation: Kountche AB, Kane N, Ousseini IS, Vigouroux Y (2013) Crop Adaptation to Biotic and Abiotic Conditions: Going Wild with Next Generation Sequencing Technologies. Agrotechnol 2: e103. doi:10.4172/2168-9881.1000e103

Page 2 of 2

4. Emerson KJ, Merz CR, Catchen JM, Hohenlohe PA, Cresko WA, et al. (2010). Resolving postglacial phylogeography using high-throughput sequencing. Proc Natl Acad Sci USA 107: 16196-16200

5. Elshire RJ, Glaubitz JC, Sun Q, Poland JA, Kawamoto K, et al. (2011). A robust, simple genotyping-by-sequencing (GBS) approach for high diversity species. PLoS ONE 6: e19379.

6. Guarino L, Lobell BD (2011) A walk on the wild side. Nature Climate Change 8: 374-375.

7. Vigouroux $Y$, McMullen M, Hittinger CT, Houchins K, Schulz L, et al. (2002) Identifying genes of agronomic importance in maize by screening microsatellites for evidence of selection during domestication. Proc Natl Acad Sci USA 99: 9650-9655.

8. Clotault J, Thuillet AC, Buiron M, De Mita S, Couderc M, et al. (2012)
Evolutionary history of pearl millet (Pennisetum glaucum [L.] R. Br.) and selection on flowering genes since its domestication. Mol Biol Evol. 29: 11991212.

9. Saïdou AA, Mariac C, Luong V, Pham JL, Bezançon G and Y Vigouroux. (2009) Association studies identify natural variation at PHYC linked to flowering time and morphological variation in pearl millet. Genetics 182: 899-910.

10. Mariac C, Jehin L, Saïdou AA, Thuillet AC, Couderc M, et al. (2011) Genetic basis of pearl millet population adaptation along an environmental gradient investigated by a combination of genome scan and association mapping. Mo Ecol 20: 80-91.

11. De Mita S, Thuillet AC, Gay L, Ahmadi N, Manel S, et al. (2013). Detecting selection along environmental gradients: analysis of eight methods and their effectiveness for outbreeding and selfing populations. Mol Ecol 22: 1383-1399. 